\title{
The Effect Of Insulin Induced Acute Hypoglycemia on Brain Neurotransmitters and Oxidative Stress, Possible Protection by Gabapentin And Olanzapine
}

\author{
Alaa Kadhem Alwan', Hadaf A. ALJunaiyeh ${ }^{2}$ \& Nabeel A. J. Ali ${ }^{3}$ \\ ${ }^{1}$ B.Sc. (Pharmacy), Thi-Qar Health Office, Republic of Iraq. \\ ${ }^{2}$ Assistant Professor, Department Of Pharmacology, College Of Medicine, University of \\ Thi-Qar, Iraq. \\ ${ }^{3}$ Professor , Department Of Pharmacology, College Of Medicine, University of Basrah, \\ Iraq.
}

Hadaf.a@utq.edu.iq $^{2}$

\section{Summary}

Background, Diabetes mellitus is one of the most common metabolic diseases in the world and the number of its patients still growing and according to the International Diabetes Federation reach 552 in 2030. Hypoglycemia is dangerous adverse effect of insulin therapy and remains an unsolved problem; During hypoglycemia lack of glucose supply to neurons can lead to confusion, seizures, brain damage which is sometimes irreversible and can even cause death. Aim ,The study designed to test the effect of acute insulin induced hypoglycemia on: 1)the brain oxidative status as measured by Malondialdehyde (MDA). 2)brain neurotransmitters; dopamine, $\gamma$-Amino butyric acid (GABA)and noradrenaline. And Possible protective effect of gabapentin and olanzapine against hypoglycemia. Method and Materials, 32 male rabbits, randomly divided into four groups, group A (control group) treated with $(2.5 \mathrm{ml} / \mathrm{kg}$ ) distilled water orally and $(0.1 \mathrm{ml} / \mathrm{kg})$ distilled water subcutaneously. Group B (Hypoglycemic group) treated with $(2.5 \mathrm{ml} / \mathrm{kg})$ distilled water orally and $(1 \mathrm{IU} / \mathrm{kg})$ insulin subcutaneously. Group $\mathrm{C}$ (hypoglycemic group + gabapentin) given $(25 \mathrm{mg} / \mathrm{kg})$ gabapentin orally and (1 IU/kg) insulin subcutaneously. Group D (hypoglycemic group + olanzapine) treated with $(2 \mathrm{mg} / \mathrm{kg})$ olanzapine orally and $(1 \mathrm{IU} / \mathrm{kg})$ insulin subcutaneously. Blood samples used to determine glucose level and brain tissue used to estimation neurotransmitters. Statistics, Results are presented as the mean $\pm \mathrm{Sd}$. Statistical significance was set at $\mathrm{P}<$ 0.05 and determined by the (SPSS) version 22. Data were analyzed by one-way ANOVA and unpaired t-test. Results, Insulin treated group show significantly increased of MDA and noradrenaline in comparison to control group. In (insulin + gabapentin) treated group show significant decreased of dopamine and no significant changes of GABA and noradrenaline in comparison to control group. While (insulin + olanzapine) result was significantly increased of MDA and decreased of both dopamine and GABA in comparison to control group. On other side the use of gabapentin with insulin lead significant decreased of MDA and dopamine, significantly decreased of noradrenalin and Significant decreased of glucose levels at day one 10 AM, in comparison to use insulin only. While addition olanzapine to insulin show the following result no significantly increased of MDA, Significant decrease of dopamine and GABA and No significant 
decreased of noradrenaline in comparison to use insulin only. Conclusion, Insulin hypoglycemia lead to oxidative stress and brain neurotransmitters disturbance which are partly reversed by gabapentin and olanzapine, on the other hand both drugs tend to exacerbate insulin induced hypoglycemia. Caution should be excreted when giving any of the two drugs in such situation.

Keywords: Hypoglycemia; Insulin; Gabapentin; Olanzapine; MDA; Dopamine, GABA; Noradrenaline

\section{Introduction}

Hypoglycemia is a common and greatly feared complication of type 1 diabetes ${ }^{(\mathbf{1})}$, it's a dangerous side effect of insulin therapy and remains a big problem $^{(2)}$. Glucose is a fuel for the brain and its plasma level must be maintained within a relatively narrow range ${ }^{(3)}$, when the brain tissues doesn't get glucose, cognitive impairment and coma will occur ${ }^{(4)}$. In humans, the physiological concentration of glucose in plasma is about $3.9-6.1 \mathrm{mmol} / \mathrm{l}$ or $(70-110$ $\mathrm{mg} / \mathrm{dl}$ ), and the corresponding level in the normal brain varies between 1and $2 \mathrm{mmol} / \mathrm{g}$, hypoglycemia arises when the glucose concentration is below the normal range ${ }^{(5)}, 70 \mathrm{mg} / \mathrm{dl}$ which is the recommended lower target for blood glucose and below $70 \mathrm{mg} / \mathrm{dl}$ is considered hypoglycemia $^{(6)}$. The American Diabetes Association and Endocrine Society defined hypoglycemia in patients with diabetes "as all episodes of an abno-rmally low plasma glucose concentration that expose the patient to potential harm" (7). Also hypoglycemia defined by blood glucose level of $<70 \mathrm{mg} / \mathrm{dl}$ by various authorities including: European Medicines Agency, American Diabetes Association and
Canadian Diabetes Association ${ }^{(\mathbf{8})}$. The signs and symptoms of hypoglycemia can be divided into: adrenergic symptoms that mediated by noradrenaline released from sympath-etic adrenergic neurons, the adrenal medulla, and by acetylcholine released from cholinergic neurons these symp-toms include sweating, anxiety, tremor, nausea, and palpitations; and neuroglycopenic symptoms resulting from lack of glucose in the brain include weakness, difficulty in concentrating, irritability, visual changes, seizure, coma and death ${ }^{(9)(3)}$. According to Willis WD, et al.2013(10), in all hypoglycemic episodes per a year there are $13 \%$ of patients reported one to two sever hypoglycemia; and no significant differences between countries in the overall frequency and distribution of major hypoglycemia. The incidence of sever hypoglycemia is $1.3 \%$ per year in type 1 diabetes and $0.5 \%$ per year in type 2 diabetes (treated with insulin) ${ }^{(\mathbf{1 1})}$, although the risk of hypoglycemia is greatest among patients with T1DM, the risk of hypo-glycemia with T2DM increases with the duration of the disease and treatment approaches ${ }^{(\mathbf{1 2})}$. Many studies that included patients with 
T1DM have demonstrated that approximately $2 \%$ to $4 \%$ of patients with insulin-treated diabetes died from hypoglycemia ${ }^{(\mathbf{1 3})}$. In 1921 Banting and McLeod isolated insulin from the pancreatic islets, then in 1923 Nobel Prize was given to them for discovering insulin ${ }^{(14)}$, this discovery of insulin changed the landscape and improved life expectancy of type 1 diabetes ${ }^{(15)}$, but hypoglycemia being as problem in insulin therapy ${ }^{(2)}$. Normally the oxidation of glucose provides most of the energy needed for brain function, the brain cannot synthesis glucose and has reserves (glycogen) sufficient for only a few minutes. That mean the function of brain is totally dependent upon a continuous supply of glucose from arterial circulation. The transport of circulating glucose into cerebral cells is an insulin-independent process that requires the presence of facilitative glucose transport proteins, GLUT1, GLUT3 and GLUT4 ${ }^{(\mathbf{1 6})}$ Severe hypoglycemia led to lethal damage of the brain cell. The area and the intensity of the damage vary between individuals. The cerebrum is most defenseless, while the cerebellum is more resistant to low glucose availability ${ }^{(5)}$. The cellular mechanisms of these damage related to the mitochondria, it is one of earliest consequences and leads to a reduced ATP level and imbalance in electrolyte homeostasis, where $\mathrm{K}+$ leaves and $\mathrm{Ca}+2$ enters the neurons. The elevated intracellular $\mathrm{Ca}+2$ alters permeability of the inner mitochondrial membrane, and this allows small molecules to enter and cause swelling and damage of mitochondria, as a consequence of the latter, cytochrome $\mathrm{c}$ increase, which is normally involved in initiation of apoptosis of brain cells (5) . Free radicals are atoms have unpaired electrons which are unstable and highly reactive. Oxidative stress is "imbalance between the production and elimination of free radicals". Elimination occurs through the protection mechanisms named antioxidant systems. Free radicals overcome leads to organs damages .Oxidative damage of cells can be caused by free radicals, as super oxides and their derivatives, the reactive oxygen species (ROS). It is expressed in an organism during normal metabolism (17) If the production of ROS occurs in large amount and in the wrong place, they can cause damage to lipids, proteins, and DNA also lead to mutagenesis and carcinogenesis. They can cause changes in cell membranes and function of receptors and modify enzymes and genes activity ${ }^{(\mathbf{1 8})}$. Lipid peroxidation result from increase of pro inflammatory cytokines that produce free radicals and excessive metabolism of monoamines. Lipid peroxidation can damage neurons, decreases stability of membranes and disturb the ion channels, also affects neurotransmitters release. Malondialdehyde (MDA) formed from polyunsaturated fatty acids, as arachidonic acid represents an end product of peroxidation. It's considered as an important marker of cellular damage induced by oxidative stress $^{(17)}$. The central nervous system (CNS) is sensitive to free radical 
damage because of low antioxidant capacity, increased fatty acid metabolism in hypoglycemia may lead to acidosis, which enhances free radical aggressively ${ }^{(\mathbf{1 9})}$. The human brain is a complicated organ with 50100 billion nerve cells (neurons). The Neurons release chemicals called neurotransmitters in the space between neurons, neurotransmitters are very important natural compounds that regulate different physical and pain responses. All function in the body controlled by neurotransmitters such as noradrenaline, dopamine and gamma-amino butyric (GABA) $)^{(20)}$, it is reported that changes in neurotransmitters Quantity in several brain regions involves the development of many neurodegenerative disease ${ }^{(21)}$ Noradren-aline Is an excitatory neurotransmitter that is responsible for stimulatory processes in the body, it is an important in sympathetic system where this system cause stimulation of the heart, blood vessels, sweat glands, the large internal organs also present in most circuits in the brain, low levels of noradrenaline are associated with low energy. Excess noradrenaline can lead to fear and anxiety, as in different anxiety disorders ${ }^{(22)}$. Noradrenaline makes action through adrenergic receptors ,classically divided into $\alpha$ - and $\beta$-adrenoceptors. $\alpha$-Adrenoceptors are classified into sub- types $\alpha 1 \mathrm{~A}, \alpha 1 \mathrm{~B}, \alpha 1 \mathrm{D}, \alpha 2 \mathrm{~A}$, $\alpha 2 \mathrm{~B}$, and $\alpha 2 \mathrm{C}$. And $\beta$-adrenoceptors into subtypes $\beta 1, \beta 2$, and $\beta 3^{(23)}$.
Y-Amino butyric acid (gammaamino butyric acid or GABA) is the main inhibitory neurotransmitter in the central nervous system. It reduces neuronal excitability and muscle tone ${ }^{(24)}$. GABA plays important role in the muscle tone regulation and in lowering mental stress ${ }^{(25)}$. GABA Synthesized and released from GABAergic neurons in the brain ${ }^{(24)}$.

Dopamine is the main neurotransmitter in the mammalian brain produced by dopaminergic neurons. It's Stimulate specific dopamine receptors to the regulation of various processes like: maintaining posture and movement, memory, learning up and in emotions. The Disturbances in release and action of dopamine in the brain lead to many defect and diseases.

Dopamine has widespread effects on neuronal and also non-neuronal tissues. Thus dopamine pathway, is important target of many drugs used in neuropsychiatric diseases. Gabapentin was initially introduced in 1994 as an antiepileptic drug, primarily for partial seizures, because its side effects are well tolerated and it is well absorbed after oral administration with the maximal plasma concentration seen after two hours ${ }^{(26)}$. it is also been found to be beneficial in treating neuropathic pain related to post-herpetic neuralgia (PHN), post poliomyelitis neuropathy, and diabetic neuropathy ${ }^{(27)(26)}$. Gabapentin is a structural analog of the inhibitory 
neurotransmitter gamma- amino butyric acid (GABA) figure (1)<smiles>NCCCC(=O)O</smiles><smiles>NCC1(CC(=O)O)CCCCC1</smiles>

Gabapentin

Figure (1): Chemical structure of gaba and gabapentin ${ }^{(27)}$

With the ability to cross the blood brain barrier, its bind to the accessory $\alpha 2-\delta-1$ subunit of voltage gated calcium channels (particularly the $\mathrm{N}$ and L-types), and lead to inhibit the membrane trafficking of calcium channels, then deceasing the excitability of the peripheral neurons and decrease pain sensation ${ }^{(28)}$.

Olanzapine is an atypical antipsychotic with mood stabilizing properties. It is an agonist of serotonin receptors $5 \mathrm{HT} 2 \mathrm{~A}-2 \mathrm{C}$, and simultaneously anta- gonist of serotonin 5HT1, 5HT3, 5HT6, 5HT7, dopamine (D1-D5), muscarinic acetylcholine $\quad(\mathrm{m} 1-\mathrm{m} 5), \quad \alpha 1-$ adrenergic, and histamine (mostly H1) receptors ${ }^{(29)}$. Olanzapine first synthesized in the UK in 1982; approved by the FDA in 1996 for schizophrenia and bipolar mania ${ }^{(30)}$. The aim of research was test the effect of acute insulin induced hypoglycemia on:1) the brain oxidative status as measured by Malondialdehyde (MDA). 2) brain neurotransmitters; dopamine, $\gamma^{-}$ Amino butyric acid (GABA) and noradrenaline, and Possible protective effect of gabapentin and olanzapine against hypoglycemia.

\section{Materials and methods}

\section{Animals}

The experiments were carried out on32 locally bred, sexually mature male rabbits, their body weights ranging from 1 to $2 \mathrm{~kg}$. The animals were housed in a (12:12 hours) light/dark cycle in a temperature and humidity controlled room and free access to food and water available ad libitum. The study protocol was approved by the Ethical Committee and the Council of the College of Medicine / University of Basrah, animals were left to acclimatization for at least 3 days and Daily human contact to reduced stress ${ }^{(31)}$.

\section{Study design}

The rabbits were divided randomly into four groups (groups A, B,C and D) eight rabbits each, blood samples for estimation of blood glucose level were taken from the marginal ear vain at $2 \mathrm{hr}$ before insulin injection and at,0,2 and 4 hrs,by using accuchek active glucometer. Group A (Control Group), Rabbits in this 
group were treated with distilled water orally and subcutaneously. Group B

(Hypoglycemic Group) Rabbits in this group were treated with $(2.5$ $\mathrm{ml} / \mathrm{kg}$ ) distilled water orally and $(1$ $\mathrm{IU} / \mathrm{kg}) \quad$ insulin ${ }^{(32)}$ subcutaneously. Group C (Hypoglycemic Group + Gaba-pentin), Animals in this group were given $(25 \mathrm{mg} / \mathrm{kg})$ gabapentin orally ${ }^{(33)(34)}$ and $\quad(1 \quad \mathrm{IU} / \mathrm{kg})$ insulin subcutaneously. Group D (Hypoglycemic Group + Olanzapine), animals here were treated with $(2 \mathrm{mg} / \mathrm{kg})$ Olanzapine orally ${ }^{(35)}$ and (1 IU/kg) insulin subcutaneously, see table (1).

\section{Reagents}

Act rapid human insulin vial (Novo nordisk, Denmark), olanzapine tablet (Eli Lily, USA). Gabapentin capsule (Pfizer, USA), Hydrochloric acid (HCl), Thiobarbituric acid (TBA) C6H8N2O2S, Trichloroacetic acid (TCA ) $\mathrm{CCl} 3 \mathrm{COOH}$, Chloroform, Di-sodium hydrogen orthophosphate NaHPO4, Potassium dihydrogen orthophosphate $\mathrm{KH} 2 \mathrm{PO} 4$, Sodium chloride $\mathrm{NaCl}$, diagnostic kit for (nor-adrenaline, dopamine and gaba), also used instrument like Electrical homogenizer (Heidolph, Germany) and HumaReader HS (Human) ELISA (Germany).

\section{Blood sampling}

After overnight fasting, at 6AM of next day we record the bodyweight of each rabbit with sensitive balance then blood samples were taken as pre-experimental sampling and measure the blood glucose level to each animal, at $8 \mathrm{AM}, 10 \mathrm{AM}$ and 12 $\mathrm{AM}$ also the measurements were repeated in the second day. Free access to food after12AM and we give $1 \mathrm{ml} 50 \%$ hypertonic glucose solution to avoid animal death from hypoglycemia .

\section{Tissue handling}

In the morning of 3rd day of the experiment, the animals were sacrificed at $9 \mathrm{AM}^{(36)}$ by inhalation of an overdose of chloroform; specimens from brain (cortex) from each rabbit were immediately removed by using bone cutting forceps for opening the skull, then weighed and rinsed in freshly prepared phosphate-buffer saline $\mathrm{pH}=7.4$ and homogenized for brain Malondialdehyde (MDA) level according to the method described by ( ${ }^{37}$. then used homogenated sample for determine the brain neurotransmitters by using kits then Standard curve see figure (2), dopamine curve.

\section{Statistical Analysis}

The software used was Statistical Package for the Social Sciences (SPSS), version 22. Analysis data was expressed as mean \pm standard deviation (sd). also data were analyzed by one way ANOVA, 
Thi-Qar Medical Journal (TQMJ): Vol.(12), No.(2), 2016

unpaired t-test was used for

treatment.

comparison between different

\section{Results}

\section{MDA}

The level of brain MDA was

significantly increased to $11591.51 \pm 4090.19 \mathrm{nmol} / \mathrm{g}$ in the group treated with insulin in comparison to $6837.24 \pm 1651.93 \mathrm{nmol} / \mathrm{g}$ in the control, $\mathrm{p}(0.028)$. Also significantly increased in the group treated with (insulin + olanzapine) to $12743.30 \pm 3626.19 \mathrm{nmol} / \mathrm{g}$ in comparison to the control, $\mathrm{p}$ (0.005), while there was no significant difference between the group treated with (insulin+ Gabapentin) and control, where the value of MDA was $6883.21 \pm 2824.49 \mathrm{nmol} / \mathrm{g}$ in (insulin + Gabapentin) comparison to 6837.24 $\pm 1651.93 \mathrm{nmol} / \mathrm{g}$ of the control, $\mathrm{p}(1.0)$. MDA level was significantly decreased to6883.21 $\pm 2824.49 \mathrm{nmol} / \mathrm{g}$ in the group treated with (insulin + Gabapentin) in comparison with $11591.51 \pm 4090.19 \mathrm{nmol} / \mathrm{g}$ (in the group treated with insulin alone), $\mathrm{p}(0.03)$. Data are shown in table 2, fig.3-A.

\section{Dopamine}

The mean level of brain dopamine in the control group was $1061.50 \pm 15.27 \mathrm{pg} / \mathrm{ml}$ and this level was not significantly changed in the group that treated with insulin $1042.37 \pm$ $18.93 \mathrm{pg} / \mathrm{ml}, \mathrm{p}(0.973)$. The level dopamine significantly reduced in the group that treated with (insulin + Gabapentin) $863.12 \pm 90.25 \mathrm{pg} / \mathrm{ml}$ in comparison to $1061.50 \pm$ 15.27 of the control, $\mathrm{p}(0.000)$.Also the dopamine significan-tly reduced in the group that was treated with (insulin + olanzapine) to $828 \pm 152.64 \mathrm{pg} / \mathrm{ml}$ in comparison to $1061.50 \pm 15.27 \mathrm{pg} / \mathrm{ml}$ of the control, $\mathrm{p}(0.001)$. The level of brain dopamine in insulin was $1042.37 \pm 18.93 \mathrm{pg} / \mathrm{ml}$ and this level was significantly different from both (insulin+ gabap-entin) group (insulin + olanzapine), $\mathrm{p}<0.05$.see table 2, fig.3- B.

\section{GABA}

The mean level of brain GABA in control group was $240.58 \pm 20.44 \mathrm{ng} / \mathrm{ml}$ and this level was not significantly changed in the group treated with insulin 229.18 \pm 27.89 $\mathrm{ng} / \mathrm{ml}, \mathrm{p}(0.877)$. And in the group treated with (insulin + Gabapentin) where the mean level was $231.68 \pm 25.42 \mathrm{ng} / \mathrm{ml}, \mathrm{p}(0.773)$. The mean level of GABA in the insulin + olanzapine) group was $194.87 \pm 20.28 \mathrm{ng} / \mathrm{ml}$ and this level was significantly reduced when compared to the control, (insulin + Gabapentin) and (insulin + olanzapine) group, $\mathrm{p}<0.05$. see table 2 , fig.3-C. 
Thi-Qar Medical Journal (TQMJ): Vol.(12), No.(2), 2016 


\section{Noradrenaline}

The mean level of brain noradrenaline was significantly increased to19.37 $\pm 4.65 \mathrm{ng} / \mathrm{ml}$ in the group that treated with insulin in comparison to $11.55 \pm 4.9 \mathrm{ng} / \mathrm{ml}$ in the control, $\mathrm{p}$ (0.033). The level of noradrenaline in the group treated with (insulin + Gabapentin) was $10.55 \pm 3.12 \mathrm{ng} / \mathrm{ml}$, and this level was not significantly different from the control group, $\mathrm{p}$ (0.982). The noradrenaline level in insulin group was $19.37 \pm 4.65 \mathrm{ng} / \mathrm{ml}$, and this level was significantly different from (insulin + Gabapentin) group where the level was $10.55 \pm 3.12 \mathrm{ng} / \mathrm{ml}$, p (0.014), and not significantly different from the (insulin +olanzapine) group where the level was $12.53 \pm 7.67 \mathrm{ng} / \mathrm{ml}, \mathrm{p}(0.074)$. There was no significant difference between (insulin + Gabapentin) group and (insulin + olanzapine) group, see table 2. fig.3-D.

\section{Glucose}

There was no significant difference between all groups at 6 am and $8 \mathrm{am}$ (8am is base line or $0 \mathrm{hr}$ time) in all three day, $\mathrm{p}>0.05$. There was significant decreased in glucose level in all groups that used insulin at 10am ( $2 \mathrm{hr}$ after insulin injection) in day one and day two, also at 12am (4hr after insulin injection) in day one and day two, also at 9am (1hr after insulin injection) in day three in comparison to control. Also there was significant decreased in glucose level in (insulin + Gabapentin) treated group at 10am ( $2 \mathrm{hr}$ after insulin injection) in day one $(32.62 \pm 10 \mathrm{mg} / \mathrm{dl})$, in comparison to $(48.62 \pm 16$ $\mathrm{mg} / \mathrm{dl})$ of insulin group, $\mathrm{p}(0.032)$, see table 3 ,fig. 4 .

Table (1): Study Design

\begin{tabular}{|c|c|c|c|}
\hline Group & Day One & Day Two & Day Three \\
\hline $\mathbf{A}$ & $\begin{array}{ll}6 \text { A.M } & \text { D.W. Oral } \\
8 \text { AM } & \text { D.W. SC }\end{array}$ & $\begin{array}{ll}6 \text { A.M } & \text { D.W. Oral } \\
8 \text { AM } & \text { D.W. SC }\end{array}$ & $\begin{array}{ll}6 \text { A.M } & \text { D.W. Oral } \\
8 \text { AM } & \text { D.W. SC }\end{array}$ \\
\hline B & $\begin{array}{l}6 \text { A.M D.W. Oral } \\
8 \text { A.M Insulin SC }\end{array}$ & $\begin{array}{l}6 \text { A.M D.W. Oral } \\
8 \text { A.M Insulin SC }\end{array}$ & $\begin{array}{l}6 \text { A.M D.W. Oral } \\
8 \text { A.M Insulin SC }\end{array}$ \\
\hline C & $\begin{array}{l}6 \text { A.M Gabapentin Oral } \\
8 \text { A.M Insulin SC }\end{array}$ & $\begin{array}{l}6 \text { A.M Gabapentin Oral } \\
8 \text { A.M Insulin SC }\end{array}$ & $\begin{array}{l}6 \text { A.M Gabapentin Oral } \\
8 \text { A.M Insulin SC }\end{array}$ \\
\hline D & $\begin{array}{l}6 \text { A.M Olanzapine Oral } \\
8 \text { A.M Insulin SC }\end{array}$ & $\begin{array}{l}6 \text { A.M Olanzapine. Oral } \\
8 \text { A.M Insulin SC }\end{array}$ & $\begin{array}{l}6 \text { A.M Olanzapine. Oral } \\
8 \text { A.M Insulin SC }\end{array}$ \\
\hline
\end{tabular}




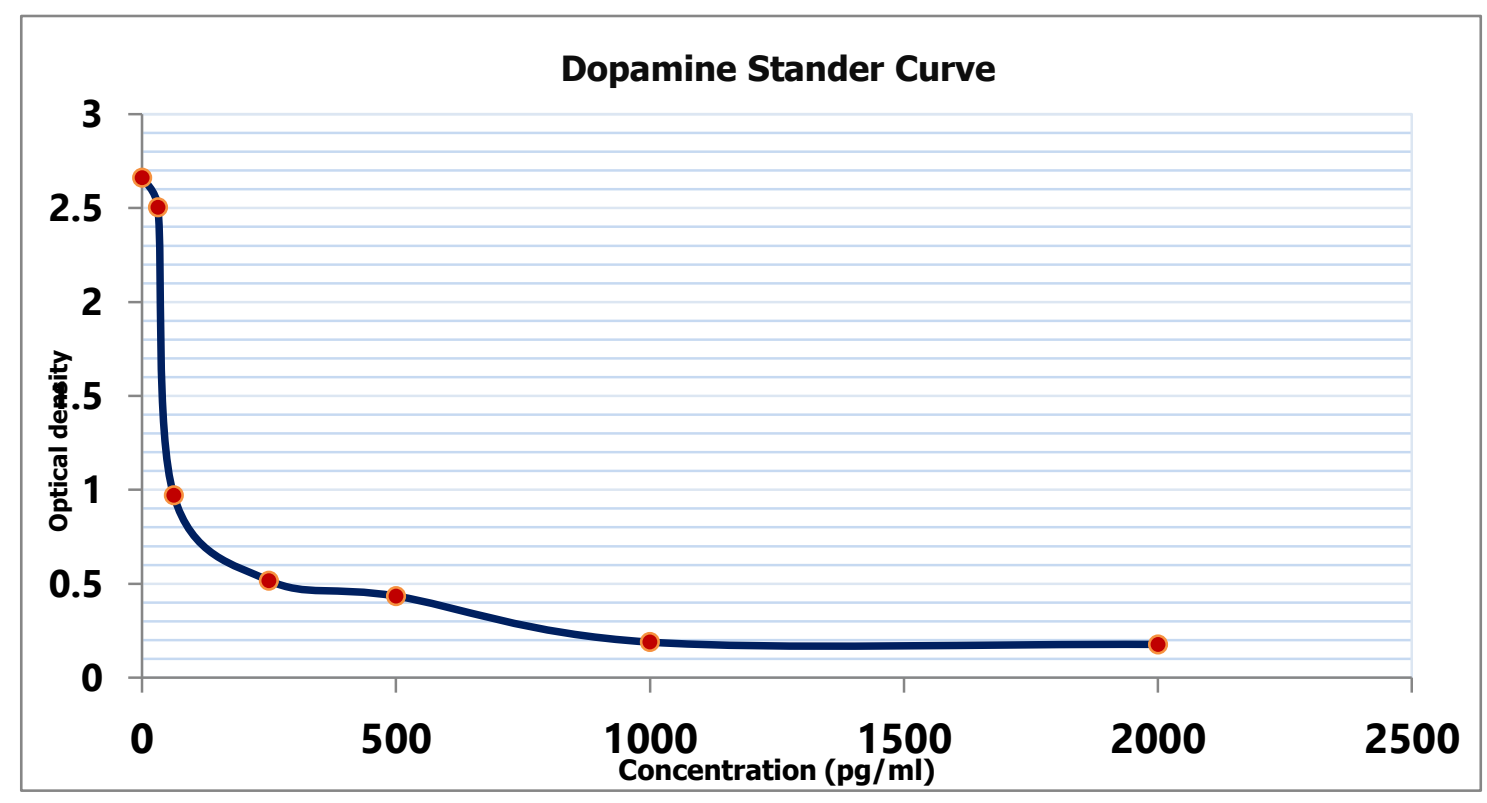

Figure (2) : Standard Calibration Curve for Brain Tissue Dopamine Levels Estimation

Table (2 ) :The Effect of Different Treatments on Brain MDA, Dopamine, GABA and Noradrenaline

\begin{tabular}{|c|c|c|c|c|}
\hline Group & $\begin{array}{c}\text { MDA } \\
(\mathrm{mmol} / \mathrm{g})\end{array}$ & Dopamine (pg/ml) & $\begin{array}{l}\text { GABA } \\
(\mathrm{ng} / \mathrm{ml})\end{array}$ & Noradrenaline \\
\hline Control & $\begin{array}{l}6837.24 \\
1651.93\end{array} \quad \pm$ & $1061.50 \pm 15.27$ & $240.58 \pm 20.44$ & $11.55 \pm 4.9$ \\
\hline Insulin & $\begin{array}{l}11591.51 \\
4090.19 \\
*\end{array}$ & $1042.37 \pm 18.93$ & $229.18 \pm 27.89$ & $\begin{array}{c}19.37 \pm 4.65 \\
*\end{array}$ \\
\hline $\begin{array}{l}\text { Insulin + } \\
\text { Gabapentin }\end{array}$ & $\begin{array}{l}6883.21 \pm 2824.49 \\
\#\end{array}$ & $\begin{array}{c}863.12 \pm 90.25 \\
* \#\end{array}$ & $231.68 \pm 25.42$ & $\begin{array}{c}10.55 \pm 3.12 \\
\#\end{array}$ \\
\hline $\begin{array}{l}\text { Insulin }+ \\
\text { Olanzapine }\end{array}$ & $\begin{array}{l}12743.30 \pm 3626.19 \\
*\end{array}$ & $\begin{array}{c}828 \pm 152.64 \\
* \#\end{array}$ & $\begin{array}{c}194.87 \pm 20.28 \\
* \# \$\end{array}$ & $12.53 \pm 7.67$ \\
\hline
\end{tabular}

* Significant Difference from Control / \# Significant Difference from Insulin / \$ Significant Difference from ( Insulin + Gaba ) 


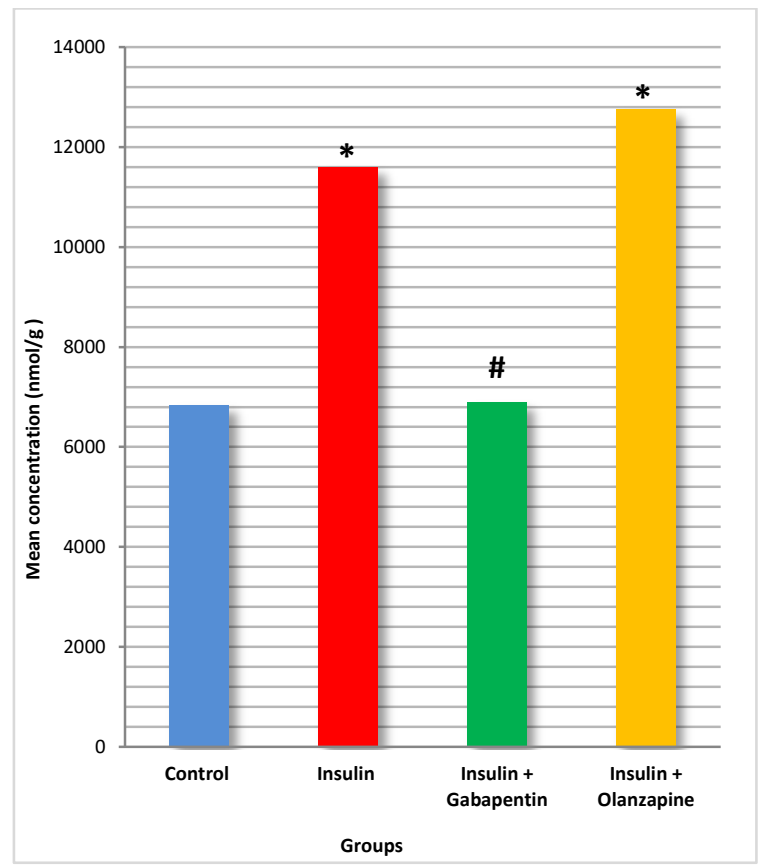

3- A

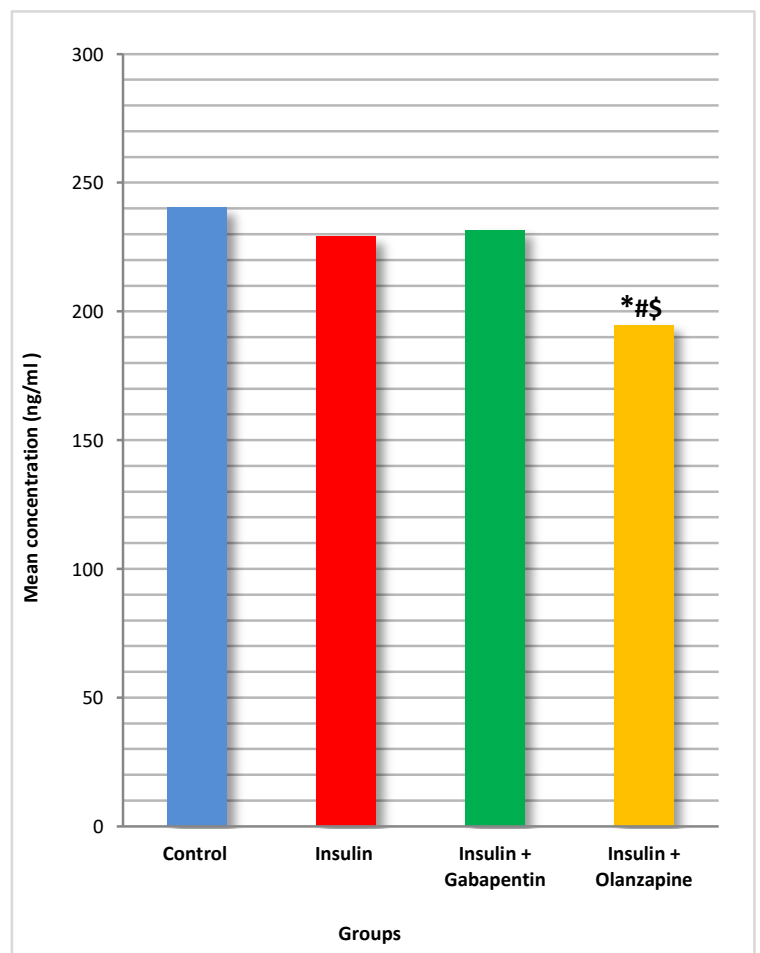

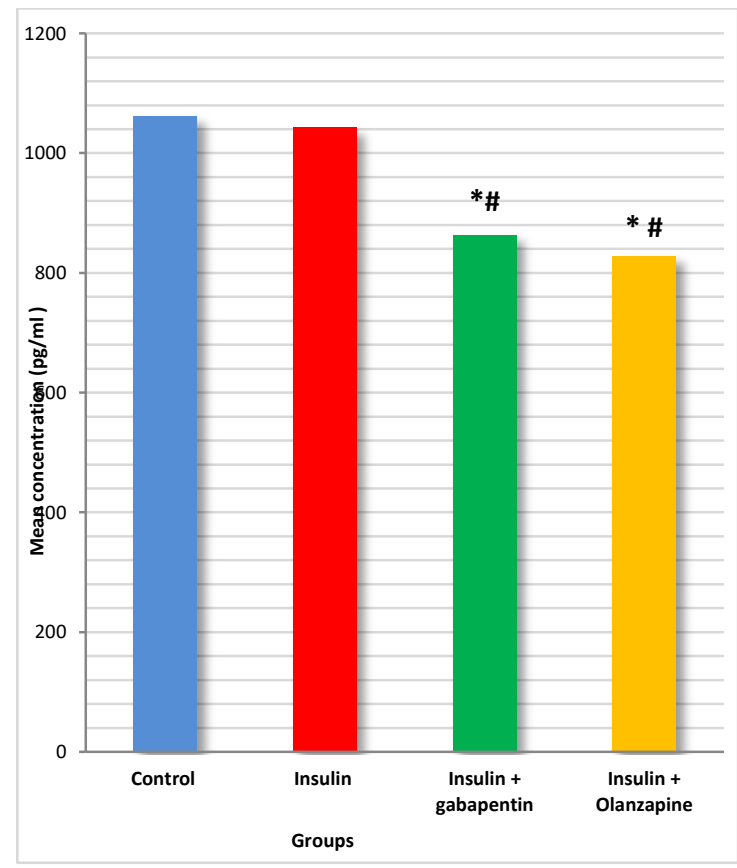

3- B

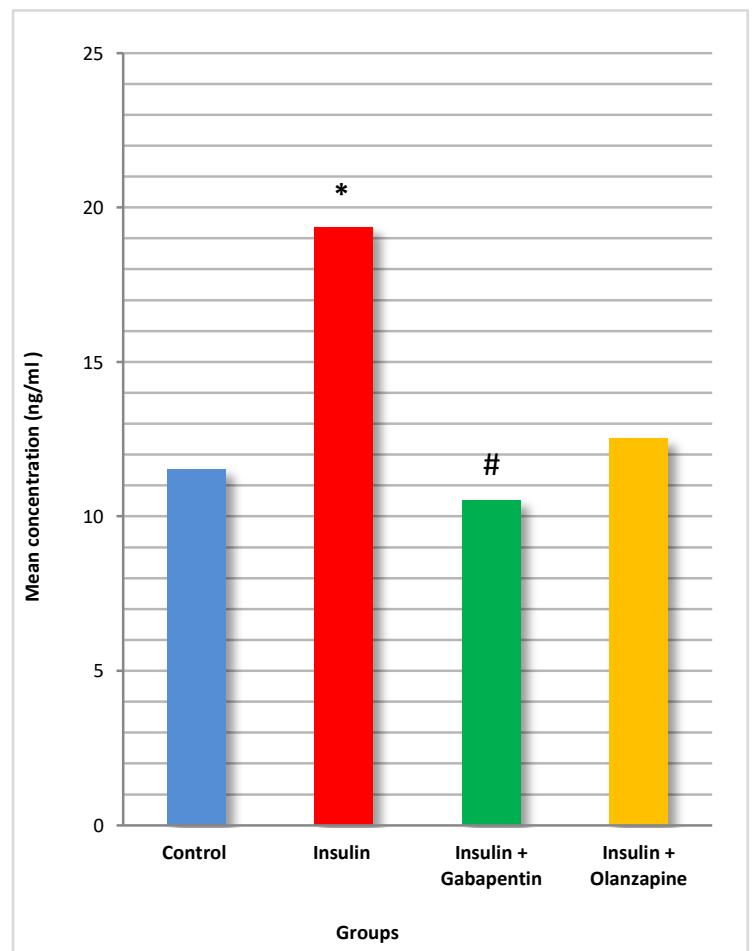

* Significant difference from control / \# Significant difference from insulin / \$ Significant difference from ( Insulin + Gaba )

Figure (3): A) Mean of MDA in various groups. B) Mean of Dopamine in various groups. C) Mean of GABA in various groups. D) Mean of Noradrenaline in various groups, 
Table (3) : The Effect of Different Treatment on Blood Glucose level.

\begin{tabular}{|c|c|c|c|c|c|c|c|c|}
\hline \multirow{3}{*}{ Group } & \multicolumn{8}{|c|}{ Mean \pm SD } \\
\hline & \multicolumn{4}{|l|}{ Day one } & \multicolumn{4}{|c|}{ Day two } \\
\hline & $6 \mathrm{am}$ & 8 am & $10 \mathrm{am}$ & $12 \mathrm{am}$ & $6 \mathrm{am}$ & 8 am & $10 \mathrm{am}$ & $12 \mathrm{am}$ \\
\hline Control & $\begin{array}{c}69.37 \\
\pm 6\end{array}$ & $\begin{array}{c}78.37 \\
\pm 5\end{array}$ & $\begin{array}{r}70 \\
\pm 9\end{array}$ & $\begin{array}{c}67.37 \\
\pm 8\end{array}$ & $\begin{array}{r}68 \\
\pm 5\end{array}$ & $\begin{array}{c}72.5 \\
\pm 6\end{array}$ & $\begin{array}{c}75.62 \\
\pm 6\end{array}$ & $\begin{array}{c}61.37 \\
\pm 9\end{array}$ \\
\hline Insulin & $\begin{array}{c}68.25 \\
\pm 9\end{array}$ & $\begin{array}{c}75.75 \\
\pm 13 \\
\end{array}$ & $\begin{array}{c}48.62 \\
\pm 16\end{array}$ & $\begin{array}{c}48.75 \\
\pm 13 \\
\end{array}$ & $\begin{array}{c}70.87 \\
\pm 9\end{array}$ & $\begin{array}{r}71.37 \\
10 \\
\end{array}$ & $\begin{array}{c}39.62 \\
\pm 19\end{array}$ & $\begin{array}{l}39.5 \\
\pm 16\end{array}$ \\
\hline $\begin{array}{l}\text { Insulin } \\
\text { Gabapentin }\end{array}$ & $\begin{array}{c}76.62 \\
\pm 10\end{array}$ & $\begin{array}{c}72.12 \\
\pm 11\end{array}$ & $\begin{array}{c}32.62 \\
\pm 10\end{array}$ & $\begin{array}{c}47.87 \\
\pm 14\end{array}$ & $\begin{array}{c}75.5 \\
\pm 7\end{array}$ & $\begin{array}{c}76.37 \\
\pm 11\end{array}$ & $\begin{array}{c}29.37 \\
\pm 10\end{array}$ & $\begin{array}{c}35.12 \\
\pm 9\end{array}$ \\
\hline $\begin{array}{l}\text { Insulin } \\
\text { Olanzapine }\end{array}$ & $\begin{array}{c}69.12 \\
\pm 7\end{array}$ & $\begin{array}{r}73.5 \\
\pm 19\end{array}$ & $\begin{array}{c}42.87 \\
\pm 13\end{array}$ & $\begin{array}{c}48.87 \\
\pm 16\end{array}$ & $\begin{array}{c}69.25 \\
\pm 13\end{array}$ & $\begin{array}{c}73.37 \\
\pm 6\end{array}$ & $\begin{array}{c}34 \\
\pm 16\end{array}$ & $\begin{array}{c}35.37 \\
\pm 13\end{array}$ \\
\hline
\end{tabular}

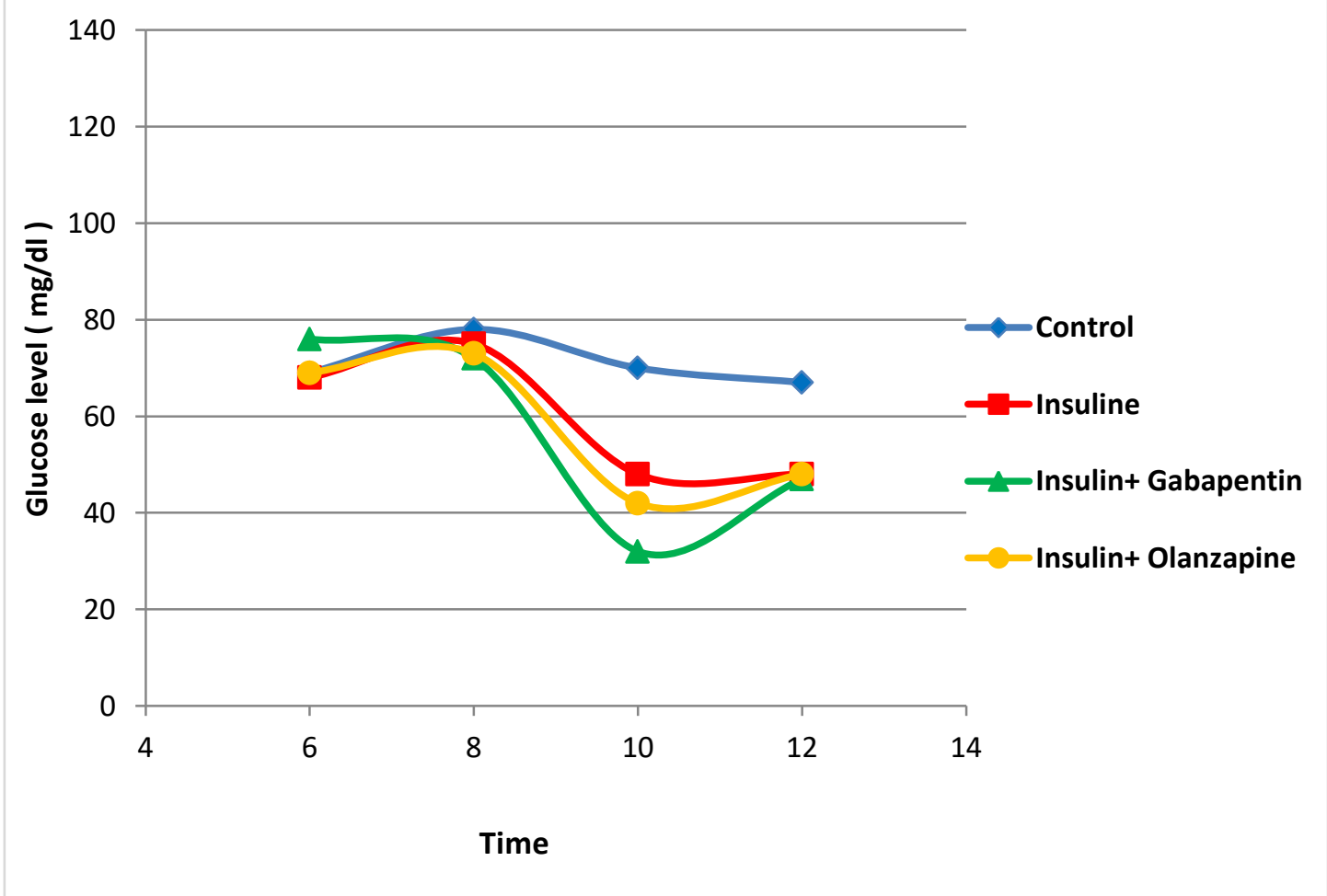

Figure (4) : The effect of different treatment on blood glucose level at day one 


\section{Discussion}

The brain play a central role in the counter-regulatory responses ${ }^{(\mathbf{3 8})}$. In this study insulin significantly increased MDA in the brain tissue, this effect is probably mediated by hypoglycemia on the brain cells, and it is in agreement with other studies ${ }^{(19)}$. The mechanism by which such effect mediated, is by enhancing mitochondrial damage, that lead to imbalance between production and inactivation of oxygen free radicals ${ }^{(\mathbf{1 9})}$.While gabapentin reverse the effect of insulin on brain tissue MDA levels back toward normal value. Gabapentin was found to be protective against ischemic injury ${ }^{(39)}$, this may be mediated by inhibition the activation of glutamate receptors specially (N-methyl D-aspartate NMDA), where this receptor play important role in the cell death. Glucose depletion lead to increase of glutamate that lead to over activation of NMDA receptor this lead to mitochondrial dysfunction and increase ROS, super oxides,hydrogen peroxides and $\mathrm{Ca}+2$ influx in the cytoplasm lead to cell death ${ }^{(39)(40)}$. Olanzapine on the other hand failed to reduce the brain tissue MDA levels and slightly increase this mediator, but this was statistically not significant, this is in agreement with other study ${ }^{(41)}$. Insulin has no significant effect on brain tissue dopamine when comparison with control, this in agreement with other study ${ }^{(42)}$, gabapentin significantly reduced brain tissue dopamine, also olanzapine causes, significant reduction of dopamine when comparison with both control and insulin groups and the suggested mechanism is olanzapine cause reduction of the stimulation of dopaminergic function in the brain ${ }^{(43)}$. The different treatments has no significant effect on brain tissue GABA levels and this in agreement with other study ${ }^{(44)}$, exception to these is the combination of insulin and olanzapine that produced a significant reduction in GABA and this in agreement with other study $^{(45)}$ which suggests that olanzapine lead to increased activity of cortical afferents neurons, and effect the GABAergic neurons that mediate the potentiation of the excitatory postsynaptic potentials. Gabapentin reverse the insulin effect where its significantly decreased the noradrenaline level when compared with insulin group. This is in agreement with many other studies ${ }^{(46)}$, and it may be due to gabapentin lead to increase the GABA, GABA lead to reduction of CNS serotonin activity where serotonin increasing during stress and leading to increasing of noradrenaline. Insulin produce a significant reduction in blood glucose level and This is agreement with many other studies ${ }^{(\mathbf{4 2})}$, olanzapine therapy was associated with hypoglycemia This is agreement with ${ }^{(47),(48)}$. The mechanism, of hypoglycemia in such cases is not known, but insulin hyper secretion is assumed to be associated ${ }^{(49)}$.Gabapentin potentiated insulin induced hypoglycemia and this effect was statistically significant during the first day of treatment. This was unexpected effect of gabapentin and we found scanty publications on the subject including case reports of gabapentin induced hypoglycemia in both diabetic and nondiabetic patients ${ }^{(50)}$. The possible the mechanism could be duo to the activation of the GABA-A receptor leads to membrane depolarization and 
subsequent calcium influx, the activation of the GABA-A receptor leads to membrane depolarization ${ }^{(50)}$.

\section{Conclusion}

1. Insulin induced hypoglycemia produce an acute oxidative stress on the brain tissue.

2. This was associated with disturbances in the brain neuro-transmitters including dopamine, noradrenaline and gaba.

3. This could be the cause or effect of the neuronal damage occurring during or following repeated hypoglycemic episodes.

4. The modulation of these effects by gabapentin or olanzapine may have a therapeutic potential in the treatment or the prophylaxis against brain damage during hypoglycemia

5 .

\section{Recommendations}

1. The hypoglycemic effect of gabapentin requires further studies to explore the mechanism.

2. To study the interaction between gabapentin and insulin or oral hypoglycemic drugs

3. To screen various centrally acting drugs for neuronal protection during hypoglycemia.

\section{References}

1. Choudhary P, Rickels MR, Senior PA, Vantyghem, Paola Maffi, Thomas W. Kay, et al. Evidence-Informed Clinical Practice Recommendations for Treatment of Type 1 Diabetes Complicated by Problematic Hypo-glycemia. Diabetes Care. 2015 ;38(6):1016-102.
2. Dømgaard $M$, Bagger $M$, Rhee NA, Burton CM, Thorsteinsson B. Individual and societal consequences of hypoglycemia: A cross-sectional survey. Postgrad Med. 2015; 127(5):438-45.

3. Desimone ME, Weinstock RS. Hypoglycemia. In: De Groot LJ, BeckPeccoz P, Chrousos G, Dungan K, Grossman A, Hershman JM, Koch C, McLachlan R, New M, Rebar R, Singer F, Vinik A, Weickert MO, editors. SourceEndotext [Internet]. South Dartmouth (MA): MDText.com, Inc.; 2000-.2015 Apr 12.

4. de Galan BE, Schouwenberg BJ, Tack CJ, P. Smits . Pathophysiology and management of recurrent hypoglycemia and hypoglycemia unawareness in diabetes. Neth J Med. 2006 ;64(8):269-79.

5. Mohseni S. Neurologic damage in hypoglycemia, Handb Clin Neurol. 2014; 126:513-32.

6. Sanjay Kalra , Basal insulin analogues in the treatment of diabetes mellitus: What progress have we made? Indian J EndocrinolMetab. 2015; 19( 1): S71-S73.

7. Mazen Alsahli and John E. Gerich , Hypoglycemia in Patients with Diabetes and Renal Disease J.: Clin. Med. 2015, 4(5), 948-964.

8. Bonaventura A, Montecucco F, Dallegri F , Update on strategies limiting iatrogenic hypoglycemia. Endocr Connect. 2015. pii: EC-15-0044.

9. Michael J. Thompson and John P. Mordes . Hypoglycemia in Pancreatic Disease. American pancreatic Association. 2015; Version 1.0

10. Willis WD, Diago-Cabezudo JI, MadecHily A, and Aftab Aslam .Medical resource use, disturbance of daily life and burden of hypoglycemia in insulin-treated patients with diabetes: results from a European online survey, Expert Rev Pharmacoecon Outcomes Res.2013 ; 13(1):123-30.

11. Sämann A, Lehmann $\mathrm{T}$, Heller $\mathrm{T}$, Nicolle Müller, Petra Hartmann, Gunter B Wolf , and Ulrich A Müller. A retrospective study on the incidence and risk factors of severe hypoglycemia in primary care., FamPract. 2013 ;30(3):2903. 
12. Oyer DS, The science of hypoglycemia in patients with diabetes. Curr Diabetes Rev. $2013 ; 9(3): 195-208$

13. Cryer PE. Hypoglycemia in diabetes: pathophysiology, prevalence، and prevention. American Diabetes Association, Alexandria, VA 2009. de Galan BE, Schouwenberg BJ, Tack CJ, P. Smits . Pathophysiology and management of recurrent hypoglycemia and hypoglycemia unawareness in diabetes. Neth J Med. 2006 ;64(8):269-79.

14. Ghasemi R , Haeri A, Dargahi L, Mohamed Z, Ahmadiani A, Insulin in the brain: sources, localization and functions .Mol Neurobiol. 2013 ; 47(1):145-71.

15.Zargar AH, Type 1 diabetes guidelines: Are they enough?, Indian J EndocrinolMetab. $2015 ; 19($ Suppl 1):S1821.

16. Banks WA, Owen JB, Erickson MA. Insulin in the brain: there and back again. PharmacolTher. 2012; 136:82-93.

17. Vaváková M, Duračková Z, Trebatická J, Markers of Oxidative Stress and Neuroprogression in Depression Disorder. Oxid Med Cell Longev. 2015;2015:898393.

18. Halliwell B. The antioxidant paradox: less paradoxical now? British Journal of Clinical Pharmacology. 2013;75(3):637644.

19. Patocková J, Marhol P, Tůmová E , Oxidative stress in the brain tissue of laboratory mice with acute post insulin hypoglycemia. Physiol Res. 2003;52(1):131-5.

20. Sandilyan MB, Dening T, Brain function, disease and dementia Nurs Stand. 2015 27;29(39):36-42.

21. Kim TH, Choi J, Kim HG, Quantification of neurotransmitters in mouse brain tissue by using liquid chromatography coupled electrospray tandem mass spectrometry. J Anal Methods Chem. 2014;2014:506870.

22. Fitzgerald PJ, Elevated Norepinephrine may be a Unifying Etiological Factor in the Abuse of a Broad Range of Substances: Alcohol, Nicotine, Marijuana, Heroin, Cocaine, and Caffeine. Subst Abuse. 2013 ;7:171-83

23. PertovaaraA,The noradrenergic pain regula tion system:a potential target for pain thera py. Eur J Pharmacol. 2013 ;716(1-3):2-7.
24. Watanabe M, Maemura K, Kanbara K, Tamayama T, Hayasaki H. "GABA and GABA receptors in the central nervous system and other organs, International Review of Cytology .2002 ;213. pp. 1-47.

25. Anju P, Moothedath I, Rema Shree AB, Gamma amino butyric acid accumulation in medicinal plants without stress. AncSci Life. 2014 ; 34(2):68-72.

26. Chang CY, Challa CK, Shah J, and Jean Daniel Eloy , Gabapentin in acute postoperative pain management. Biomed Res Int. 2014;2014:631756.

27. Kukkar A, Bali A, Singh N, Jaggi AS. Implications and mechanism of action of gabapentin in neuropathic pain. Arch Pharm Res. 2013 ;36(3):237-51.

28. Boroujerdi A, Zeng J, Sharp K, Calcium channel alpha-2-delta-1 protein up regulation in dorsal spinal cord mediates spinal cord injury-induced neuropathic pain states Pain. 2011;152:649-655.

29. Chudek J, Olszanecka-Glinianowicz M, Almgren-Rachtan A, Tomasz Gabryelewicz . Evaluation of the safety profile of zolafren $(\circledR)$, a generic olanzapine formulation, in patients with bipolar disorder: a post-authorization safety study. AdvTher. 2015 ;32(5):418-28.

30. DjordjevićFilijović N, Antonijević MD, Pavlović A, Ivan Vuckovic , Katarina Nikolic, and Danica Agbaba .The stress stability of olanzapine: studies of interactions with excipients in solid state pharmaceutical formulations. Drug DevInd Pharm. 2015 ;41(3):502-14.

31. Manjeet Mapara, Betsy Sara Thomas, and K. M. Bhat, Rabbit as an animal model for experimental research. Dent Res J (Isfahan). 2012 ; 9(1): 111-118.

32. Jiang ZL, Sato T. Rise in plasma oxidized glutathione by experimental hypoglycemia. Tohoku J Exp Med. 1999 ;187(1):59-64 .

33. Pietrzak B, Czarnecka E.The effect of combined administration of ethanol and gabapentin on rabbit electroencephalographic activity. Basic ClinPharmacolToxicol. 2006 ;99(5):383$90($ A)

34. Pietrzak B, Czarnecka E. Effect of the administration of tiagabine and gabapentin on rabbit electroencephalogramactivity. J Pharm Pharmacol. 2006 ;58(10):1367-72.( B) 
35. Kapur S, VanderSpek SC, Brownlee BA, Nobrega JN..Antipsychotic dosing in preclinical models is often unrepresentative of the clinical condition: a suggested solution based on in vivo occupancy. J PharmacolExpTher. 2003;305(2):625-31.

36. Jiang Zl, Kohzuki M, Harada T, Sato T.Glutathione suppresses increase of serum creatine kinase in experimental hypoglycemia. Diabetes Res ClinPract. $2007 ; 77(3): 357-62$.

37. Ohkawa H, Ohishi N, Yagi K. Assay for lipid peroxides in animal tissues by thiobarbituric acid reaction. Anal Biochem. $1979 ; 95(2): 351-8$.

38. V. F. H. Jensen, I. B. Bøgh and J. Lykkesfeldt . Effect of Insulin-Induced Hypoglycemia on the Central Nervous System: Evidence from Experimental Studies. Journal of Neuroendocrinology . 2014; 26, 123-150.

39. Kale A, Börcek AÖ, Emmez H, Yildirim Z, Durdağ E, Lortlar N,et al. Neuroprotective effects of gabapentin on spinal cord ischemia-reperfusion injury in rabbits . J Neurosurg Spine .2011 ; 15:228237.

40. Kim YS, Chang HK, Lee JW, Sung YH, Kim SE, Shin MS, et al . Protective effect of gabapentin on N-methyl-D-aspartateinduced excitotoxicity in rat hippocampal CA1 neurons. J Pharmacol Sci. 2009 ;109(1):144-7.

41. Patel M, Bapu C, Padh H, Nivsarkar M. Olanzapine induced thrombocythemia in Sprague-Dawley rats. Drug Chem Toxicol. $2004 ; 27(4): 379-87$.

42. Guzman DC, Garcia EH, Mejia GB, Olguin HJ, Gonzalez JA, Labra Ruiz NA. Effect of morphine and lacosamide on levels of dopamine and 5-HIAA in brain regions of rats with induced hypoglycemia. Pakistan journal of biological sciences.2014; 17(2):292-296)
43. Vinish M, Elnabawi A, Milstein JA, Burke JS, Kallevang JK, Turek KC,et al . Olanzapine treatment of adolescent rats alters adult reward behaviour and nucleus accumbens function. Int $\mathbf{J}$ Neuropsychopharmacol. 2013 ;16(7):1599609.

44. Errante LD, Petroff OA. Acute effects of gabapentin and pregabalin on rat forebrain cellular GABA, glutamate, and glutamine concentrations . Seizure. 2003 ;12(5):3006.

45. Xu S, Gullapalli RP, Frost DO. Olanzapine antipsychotic treatment of adolescent rats causes long term changes in glutamate and GABA levels in the nucleus accumbens. Schizophr Res. $201 ; 161(2-3): 452-7$

46. Dooley DJ, Donovan CM, Pugsley TA. Stimulus-dependent modulation of $[(3) \mathrm{H}]$ norepinephrine release from rat neocortical slices by gabapentin and pregabalin. J Pharmacol Exp Ther. 2000 ;295(3):1086-93 .

47. Haruta I, Asakawa A, Inui A. Olanzapineinduced hypoglycemia in anorexia nervosa. Endocrine. $2014 ; 46(3): 672-3$.

48. H. Jeong Kim, Dong Wook Kim, Dong Joo Yun, Gun-Sei Oh, and Sang Hyun Jang. Olanzapine-Induced Hypoglycemic Encephalopathy: A Case Report. J Neurocrit Care 2012;5:30-32.

49. Nagamine T, Hypoglycemia associated with insulin hypersecretion following the addition of olanzapine to conventional antipsychotics. Neuropsychiatr Dis Treat. $2006 ; 2(4): 583-5$.

50. Scholl JH, van Eekeren R, van Puijenbroek EP. Six cases of (severe) hypoglycaemia associated with gabapentin use in both diabetic and non-diabetic patients. $\mathrm{Br} \mathrm{J}$ Clin Pharmacol. 2015 May;79(5):870-1 


\section{تأثير الانخفاض الحاد في سكر الدم المحدث بالانسولين على النواقل

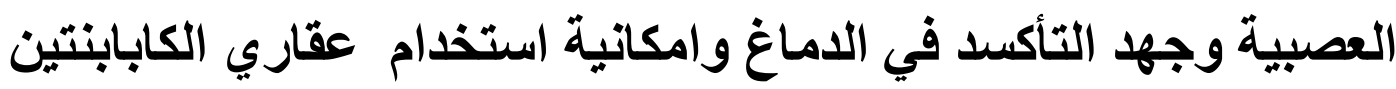

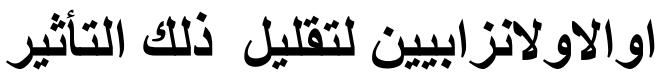

د.هدف عبدالامير حسن

د.نبيل عبدالجليل علي

ص. علاء ناظم علوان

\section{الخلاصة}

خلفية الاراسة

داء السكري هو أحد الأمراض الأيضية الأكثر شيوعا في ألعالم فوفقاً للاتحاد الدولي للسكري

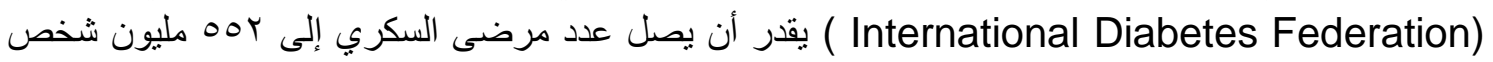

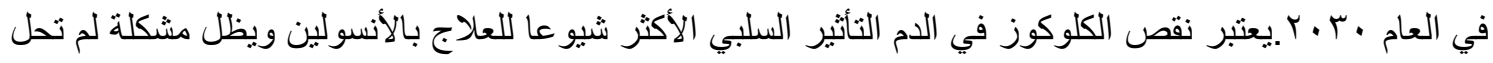

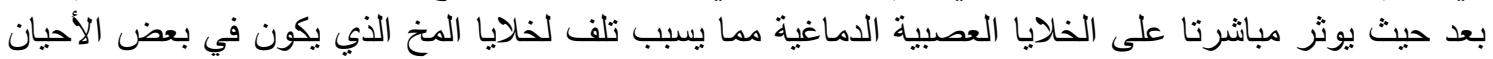
دائميا او ممينا . دئ.

$$
\text { الهُف من الاراسة }
$$

- - اختبار تأثثير النقص الحاد لمستوى كلوكوز الدم على حالة الأكسدة والنواقل العصبية بالدماغ

. (Nor adrenaline / GABA / Dopamine )

-

طريقة العمل

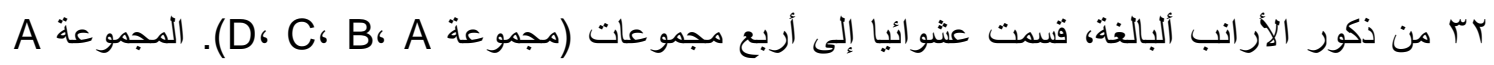

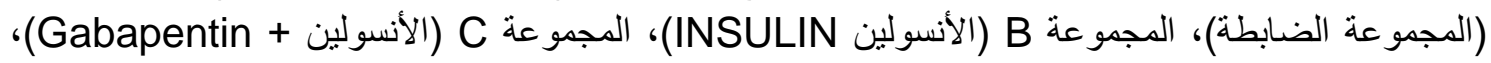

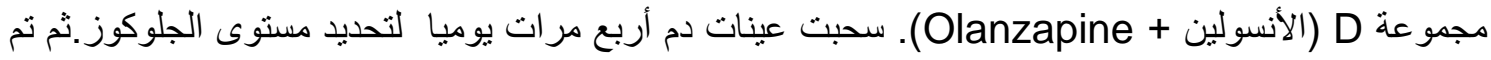
اخذ عينات من أنسجة الدماغ لقياس مستوى الأكسدة في الدماغ ومستوى النواتل العصبية بالدماغ.

النتائج

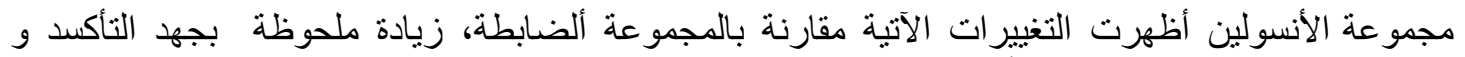
مجموعة (الأنسولين noradrenaline

الضابطة، انخفاض ملحوظ في Dopamine وعدم وجود تغير ملحوظ لكل من Gad و

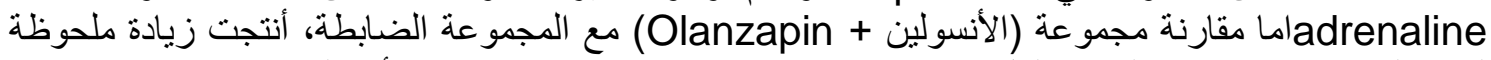

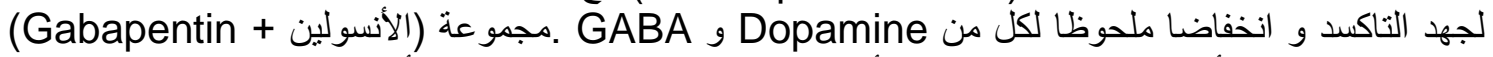
مقارنة بمجموعة الأنسولين تظهر التغييرات ألتالية انخفاض ملحوظ في جهد التأكسد و مستويات الكلوكوز و

.Nor adrenalin Dopamine

| الاستنتاج

نقص الكلوكوز في الدم الناتج من الأنسولين يؤدي الى حدوث الأكسدة واضطرابات الناقلات العصبية في

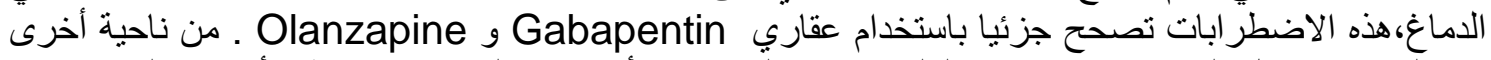

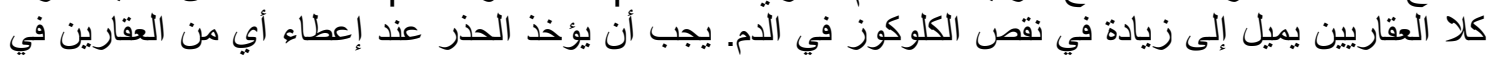
مثل هذه الحالة. 